\title{
XII yleinen kansansivistyskokous
}

Järjestyksessä VIII yleinen kansansivistyskokous pidettiin Lahdessa vuonna 1960, ja siihen osallistui noin 150 henkilöä. Kaksikymmentäkahdeksan vuotta myöhemmin eli kuluvan vuoden elokuussa kokoonnuttiin jälleen Lahdessa. Kokouksen järjestysnumero oli nyt XII, osanottajia käytännöllisesti katsoen samat 150 kuin vuonna 1960. Kokousten yhtäläisyydet — mikäli ne päättyisivät tähän - eivät antaisi aihetta enempään vertailuun, mutta nepä eivät päätykään, vai mitä on sanottava seuraavasta.

Tämänvuotisen kokouksen teema oli Elämäntavat muuttuvat - muuttuuko aikuiskasvatus. Vuonna 1960 pidettiin alustus mm. aiheesta "Vapaa sivistystyö muuttuvassa maailmassa" (Urpo Harva). Kun muiltakin osin vertailee näiden kahden kokouksen sisältöjä, on tietty perusproblematiikka hätkähdyttävän samanlaista. Jotakin on kuitenkin peruuttamattomasti muuttunut: traditionaalisen vapaan sivistystyön rinnalle on nyt tullut ammatillinen aikuiskoulutus, josta v. 1960 ei vielä näkynyt mainittavia merkkejä. Itse asiassa vapaa sivistystyö oli 1960-luvun alussa valtavan laajentumisen kauden edessä. Orıneksi se ehti monin tavoin kehittyä laadullisesti ja lisääntyä määrällisesti, ennen kuin se sai rinnalleen uuden voimakkaan tulokkaan, ammatillisen aikuiskoulutuksen.

Tämän vuoden kokouksessa jouduttiin toteamaan, että erityisesti sitten edellisen, Jyväskylässä (v. 1981) pidetyn kansansivistyskokouksen ammatillinen aikuiskoulutus on jatkanut sitä asemansa lujittamista, joka alkoi v. 1970 Aikuiskoulutuskomitean asettamisesta ja jota suuntaa valtiovalta on selväpiirteisesti tukenut. Merkille pantavaa on, ettei enää keskusteltu siitä, pitäisikö ammatillista koulutusta kehittää; nekin, jotka eivät tätä kehittämistä pidä tarpeellisena, olivat vaiti ja alistuneita. Kokouksen selvästi keskeiseksi kysymykseksi muodostuikin tietynlaisen tilannearvion jälkeen se, mikä tulee olemaan vapaan sivistystyön asema ja tehtävät 1990-luvun Suomessa.

Tuleva kasvaa menneestä. Kansansivistyskokous tarkastelikin alustuksin, keskusteluin ja ryhmätöin aikuiskoulutuksen kentän tapahtumia vuoden 1981 jälkeen sekä kysyi, mikä on aikuiskoulutuksen tilanne tänä päivänä. Kun keskeinen koontatulos tältä osin oli, että merkittävin muutos on ollut ammatillisen aikuiskoulutuksen aseman kaikinpuolinen vahvistu- minen, jäi tulevaisuuden suunta jotenkin epämääräiseksi, sillä suurin osa osallistujista edusti vapaata sivistystyötä. Selvien kehittämislinjojen jäädessä tulevaisuuden sumuun jouduttiin yhä uudelleen korostamaan, että olkoonpa ammatillisen aikuiskoulutuksen uusi asema kuinka vahva tahansa, on vapaalla sivistystyöllä oltava asemansa ja arvonsa myös tulevaisuudessa. Vapaan sivistystyön edustajien puheenvuoro toisensa jälkeen puolusti saavutettujen asemia "kyllähän nyt kuitenkin meitäkin tarvitaan" -tyyliin. Kritiikkiä ja visioita vapaasta sivistystyöstä taas esittivät ne alustajat ja keskustelijat, jotka eivät itse ammatikseen kyseistä työtä tee.

Aikaisemmin yleisissä kansansivistyskokouksissa on liikkunut ilmassa suuria aatteita isänmaallisuudesta rauhaan ja ekologisiin kysymyksiin. XII yleisen kansansivistyskokouksen perusteella voisi sanoa, että aatteet ovat kuolleet suomalaisesta vapaasta sivistystyöstä. Väite on - eritoten yhden kokouksen perusteella esitettynä - tavattoman voimakas. Sen esittäjä asettaa itsensä tietoisesti alttiiksi kritiikille ja jää odottaamaan, reakoiko väitteeseen kukaan. Saattaa olla hyväkin, ettei Lahdessa vannottu minkään asian tai arvon nimeen. Tuollainen arvo olisi voinut olla suomalaisuus, muttei oikein enää jaksettu huolestua siitä, jyrääkö ylikansallinen massaviihde tai Euroopan integraatio alleen koko suomalaisuuden. Siitä oltiin huolissaan, pystyykö vapaa sivistystyö löytämään ja käyttämään tekniikan kaikkein uusimpia mahdollisuuksia rokkisukupolven saamiseksi palvelujensa käyttäjäksi. Sitä, että Kansanvalistusseuran kirjeopisto on keksinyt mainostaa itseään Radio Cityssä ja Kansalais- ja työväenopistojen liitto tuottanut opistotoiminnan mainosvideon, pidettiin huikaisevana aluevaltauksena, suoranaisena osoituksena, että kyllä vapaa sivistystyö kehityksessä mukana pysyy. Tasa-arvo tai syrjäytymisen ongelma olisi voinut olla se aatteellinen kysymys, josta olisi voitu tehdä vaikka koko kokouksen pääasia. Mutta nehän ovat itse asiassa 1970-luvun ongelmia, onneksi kukaan ei häirinnyt kokousta ottamalla käsiteltäväksi näitä niin moneen kertaan jauhettuja kysymyksiä. Ei vetänyt vihreyskään, ei jaksettu huolestua, kuinka tälle tellukselle oikein käy, jos tämä meno jatkuu. Eikö viimeistään se, että näin oltiin "kunnallisvaalien kanssa samalla linjalla" (= vihreys ei 
enää vedä) osoita, että kansansivistysväki elää ajassa, haistaa tarkasti tuulten suunnat. Kun yhä useammin on viime aikoina puhuttu politiikan sisällyksettömyydestä ja väitetty sen olevan ainakin osasyy esim. alhaiseen äänestysaktiivisuuteen, niin vapaan sivistystyön kannattaa varmasti - tulevaisuutensa takia kysyä itseltään, onko meidän työssämme, jotta se voisi elää, oltava aatteellista sisältöä, ja jos siinä sitä on oltava, onko sitä tänä päivänä riittävästi.

Edellä sanotun tarkoituksena ei ole lähteä siitä, että kaiken vapaan sivistystyön tulisi olla syvän aatteellista ja vain sitä. Vapaalla sivistystyöllä on myös sellaisia arvokkaita tehtäviä, jotka ovat enemmän käytännöllisiä kuin aatteellisia tai jotka palvelevat enemmän yksilöllisiä kuin yhteisöllisiä tarpeita. Edellä sanotun tarkoitus on todeta, että missä muodossa tahansa kasvatusta tai koulutusta harjoitetaankin, se vaikuttaa aina jollakin tavalla. Toiminnan taustalla on aina joitakin filosofisia lähtökohtia. Jos siis vapaan sivistystyön tulevaisuuden suunta näyttää epäselvältä, voi olla, että eteenpäin päästään vain menemällä tietyllä tavalla taaksepäin. Ei välttämättä nojautumalla vanhoihin profeettoihin, vaan menemällä oman työn perimmäisiin kysymyksiin, filosofisiin lähtökohtiin. Silloin viimeistään joudutaan selvittämään suhteet myös aatteisiin ja ihanteisiin.

XII yleinen kansansivistyskokous oli kaiken aikaa "1990-luvun haasteiden edessä". Seuraavassa muutama sana siitä, mitkä asiat tuntuivat olevan niitä kysymyksiä, jotka ennen muuta olisi ratkaistava tai ainakin otettava pohdittavaksi välittömässä tulevaisuudessa.

\section{Työn identiteetti}

Kokouksessa oli kovin vähän ammatillisen aikuiskoulutuksen edustajia, niin että pohdinnat jäivät valtaosaltaan vapaan sivistystyön väen keskeiseksi ajatustenvaihdoksi. Se saatettiin todeta, että ammatillisella puolen menee hyvin. Miten se vaikuttaa lähitulevaisuudessa vapaan sivistystyön asemaan ja tehtäviin, sitä kysyttiin, sen selkiyttämistä pidettiin välttämättömänä. Se, ettei ammatillisen aikuiskoulutuksen muutoksilla olisi mitään vaikutusta vapaaseen sivistystyöhön, ei tuntunut mahdolliselta, uskottavalta.

\section{Byrokratian purkaminen}

Vapaa sivistystyö on koettanut vuosikymmeniä vaalia periaatetta, että valtion tulee maksaa työn kustannuksista suurin osa, mutta olla puuttumatta työn sisältöön. Mitä paremmat toiminnan taloudelliset ehdot eri työmuodot ovat saaneet, sitä kauemmaksi on saatettu etääntyä tästä lähtökohdasta. Tuntuu olevan selvästikin tarkistamisen, uudelleen arvioimisen aika. Mo- net toimintaa paikallis-/opintoryhmän tasolla säätelevät määräykset - usein rajoitukset eivät palvele enää mitään eikä ketään. Näin ollen osasta laajaa määräysviidakkoa voidaan luopua sekä viranomaisen että toiminnan järjestäjän hyödyksi. Kun toiveita ainakin eräiden säännösten tarkistamiseksi on olemassa, on mielenkiintoista nähdä, mitä mahdollinen muutos toisi tullessaan? Jos todelliset ongelmat olisivatkin muualla kuin väitetyssä ja aivan ilmeisen turhassa byrokratiassa, niin mitä sitten on tehtävä, jos leijonanraato saadaan poistetuksi, mutta ongelmat eivät kokonaan lopukaan? Pitääkö sitten katsoa peiliin?

\section{Oma ammattitaito}

Niin alustuksissa kuin keskustelupuheenvuoroissakin osoitettiin kiitettävää huolestumista omasta ammattitaidosta. Tunnustettiin avoimesti sen puutteellisuus. Tämä on sangen kiintoisa tosiseikka tilanteessa, jolloin aikuiskasvattajien ammattitaito on parempi kuin koskaan aikaisemmin. Se taas selittyy ennen muuta kahdesta syystä. Puutteistaan huolimatta erilaiset tiet vapaan sivistystön ammatteihin tarjoavat nykyisin paremmat valmiudet kuin koskaan aikaisemmin. Tärkeämpää kuitenkin on, että sadat, jopa tuhannet henkilöt ovat hankkineet työssä rautaisen ammattitaidon. Aikuiskasvattajan tehtävät ovat kuitenkin ainakin vapaassa sivistystyössä niin moninaiset, että hän joutuu kokemaan jatkuvaa riittämättömyyttä koulutuksesta ja kokemuksesta huolimatta, ellei huomaa panna omaa suhteellisuusjärjestelmäänsä kohdalleen; rajansa pitää olla silläkin, mitä itseltänsä vaatii, vaikka paljonkin vaatisi. Tämän asian vihonviimeiseksi lopuksi: tärkeintä oli, että Lahden kokouksen osanottajissa oli vilpitöntä halua itsensä kehittämiseen.

XII yleisen kansansivistyskokouksen alustukset ja muu paperille pantu anti tullaan julkaisemaan vapaan sivistystyön seuraavana vuosikirjana, joka jo on painossa. Lahden kaupunki ansaitsee kiitokset siitä monimuotoisesta tuesta, jota se kokoukselle antoi. Edellä esitettyyn kokousarviointiin on monien muiden varausten ohella esitettävä erityisesti yksi huomautus: minkään kokouksen merkitystä ei voi koko laajuudessaan arvioida tuoreeltaan. Voi hyvinkin olla, että ajallisen etäisyyden päästä katsottuna kuva muuttuu tuntuvastikin tai ainakin täsmentyy. Juuri nyt kuitenkin tuntuu siltä, että Lahden kokous antoi hyvän kuvan aikuiskasvatuksemme tämän päivän tilanteesta. Vaikka ei olisikaan välitöntä vastausta siihen, mihin suuntaan meidän on työssämme lähdettävä, on kuitenkin erinomainen lähtökohta tietää ja tuntea oman kentän, kokonaisuus ja läheisimmäksi koetun työmuodon asema siinä.

Timo Toiviainen 